$\begin{array}{cccc}\text { S sciendo } & \text { International Conference KNOWLEDGE-BASED ORGANIZATION } \\ \text { Vol. XXV } & \text { No } 2 & 2019\end{array}$

\title{
DETERMINING THE REMUNERATION OF THE COPYRIGHT HOLDER AND TERMINATING THE ASSIGNMENT CONTRACT
}

\author{
Tudor-Vlad SFÂRLOG \\ "Lucian Blaga" University, Sibiu, Romania \\ tsfarlog@yahoo.ro
}

\begin{abstract}
Through this study we propose new visions of the legal norms establishing the social relations between the author and the assignee in the matter of determining the remuneration and judicial review of the assignment contract. In this respect, we propose a series of amendments lex ferenda of the Law no.8 / 1996 and formulate a series of doctrinal theories that we consider will contribute significantly to the science of rights resulting from intellectual creation.
\end{abstract}

\section{Keywords: copyright, remuneration, assignment contract}

\section{Introduction}

$A b$ initio, we chose to analyse both institutions in the same subsection, as the provisions in question have, in our opinion, the same nature and are found in the same article. Thus, we consider that the place of matter is found in the provisions of art. 43 of the Law no. 8/1996 complemented with the provisions 1221-1224 of the Civil Code on the damage in the case of revision of the assignment contract.

We believe that for a pertinent analysis of the institution, we must deduce or attempt to define the notion of "remuneration" in the context of the transfer of patrimonial rights of the author. Obviously, we will start from the analysis of the term in common sense and in the sense of common law. Thus, both in common language and in the sense of common law, the "remuneration" term has the meaning of payment on the basis of the work performed. In this sense, we consider that the meaning of the term "remuneration" is sensibly different in terms of its use in the meaning of assignment contracts of patrimonial rights of the author. We make this statement in the idea that remuneration is generally attributable to working relationships subject to hierarchy. In general, remuneration is borne by an employer on the basis of the work performed. Or, in this case, the legal relationship between the parties is not determined decisively by the branch of labour law. We can even say that the author uses to a certain extent the material means of the assignee to exploit his/her patrimonial interests only to the extent that he/she wishes, because the law establishes a monopoly (even if limited in time) in the exploitation of his/her work. Furthermore, we consider that the author's remuneration is influenced, in addition to the contractual terms of the assignment contract, to the way the market will respond in relation to the quality of the work performed without major factors being relevant. In this respect, the author carries out an independent activity without being in a relationship of subordination with the assignee. 
2. The remuneration in the current Romanian law system. As regards the determination of remuneration under the contract of assignment of patrimonial rights of the author, the law mentions in the provisions of art. 43 par. (1) sentence I, as a general principle, the free negotiation of the parties. The legislator, for its part, provides for a number of points in the same provision. We consider that the references contained in the second sentence of Art. 43 par. (1) of the Law no. 8/1996 are not only meant to regulate the remuneration due to the copyright holder in the negotiation phase of the contract, but also serve as a benchmark if the provisions of the damages provided implicitly in the art. 41 par. (3) of the Law no. 8/1996 become point of law. By the provisions of art. 41 par. (1) the legislator creates a relationship of apparent equality between the copyright holder and the owner of the patrimonial rights of the author. We base this thesis on the provisions of art. 41 par. (2) and 41 (3) which establish two aptitudes only in the interest of the author, but not in the interest of the assignee. Even if we accept that this state can not occur too often, obvious disparities between benefits may also show to the detriment of the assignee. In our opinion, as there are early-stage authors tempted to accept modest offers, there will also be new publishers looking for prolific authors who will try to enter the market and accept some clearly disadvantageous conditions.

In our opinion, it must be taken into account that between the provisions of art. 43 par. (2) and (3) of Law no. 8/1996 there are a number of fundamental differences. First of all, art. 43 par. (2) governs the situation where the remuneration has not been stipulated in the contract. In this respect, the author may ask the court to determine the remuneration. In our opinion, the appreciation of the court's remuneration will be determined in view of a whole range of factors, often of high complexity. In support of this argument, the enumeration of the legislator in the art. 43 par. (2) is declarative and, we say, inaccurate. According to the law, the first criterion considered is that of the amounts normally paid for the same category of work. In our opinion, legal regulation would only be appropriate if it referred to some social relations from the labour law. Regarding the determination by the court of the remuneration due to the copyright holder, we consider the main landmark to be the proportion of the receipts from the use of the work, as it was established in the provisions of art. 43 par. (1). In our opinion, the legal purpose of the institution regulated in the art. 43 par. (2) should consist in restoring contractual equilibrium under equity.

\section{Controversy aspects in jurisprudence} In this respect, in addition to the main reference cited, the court must, in our view, consider the complexity of the assignee's work, its difficulty, the cost of multiplication, distribution or others, and establish a fair legal position regarding the patrimonial interests of the parties to the contract. In other words, even in the hypothesis of a major economic success, the court will have to answer the question: How much is due to the work and the author and what is the assignee's merit? Although at first glance it seems a simplistic regulated institution, we believe that the correct application of the provisions of art. 43 par. (2) is intended to corroborate fairly fragments of at least three branches of substantive law: civil law of contracts, patrimonial copyright and business law.

Secondly, the situation regulated by art. 43 par. (3), even if it does not expressly specify, is the premise that there is a clear disproportion between the author's performance and the unreasonably high benefits of the assignee. In this respect, the copyright owner may request the court to review the contract or to increase the remuneration in satisfactory manner. As stated [1], the copyright holder has in fact 
only the possibility of requesting a revision of the contract. In this respect, we also approve the proposals lex ferenda of the mentioned study regarding the necessary modifications to the provisions of art. 43 par. (3) of Law no. 8/1996. Furthermore, we consider that the use of the term "convenient raise" of the remuneration is not correct. In this sense, we consider that raising the salary could be convenient only when this is the result of a successful conclusion negotiated by the parties. If the increase takes place as a result of litigation, we consider that the use of the term "fair raise of the remuneration" would have been preferable. In support of these statements, we state that the court seized with such a request is under a duty, if necessary, to (re) establish the contractual equilibrium on the basis of equity, such as the request referring to the situation provided by the provisions of art. 43 par. (2).

Considering that, at least presumably, the copyright holder concludes a contract with a person specialized in signing such contracts, although not expressly stipulated, it was stated in the doctrine [2] that the provisions of art. 1221 from the Civil Code on the damaging action [3] become point of law.We consider that by applying the provisions of art. 1221 of the Civil Code, the difference between benefits is in terms of the patrimonial exploitation of the work. However, in my opinion, the disparity between benefits must exist at the time of the conclusion of the contract. Or, in the case of the assignment contract for the patrimonial rights of the author, the disproportion between the benefits is born and accentuated only after the legal act is born, while it is in existence. In another doctrinal thesis [4], it was argued that the revision of the assignment contract for the patrimonial rights of the author is based solely on the grounds of unpredictability. However, we note that, in our opinion, for the legal provisions of art. 1271 of the Civil Code to become point of law, the causes determining the incidence of the theory of imprudence must be subsequent to the conclusion of the contract and must prove a reasonable unpredictability. In this regard, we ask the following question: To what extent does a contract that is negligently negotiated with regard to the patrimonial benefits of the copyright holder may be the basis for invoking the theory of unpredictability? In our opinion, the copyright owner can not invoke the remedy of the unpredictability if he assigned certain patrimonial rights of the author against a fixed amount, and the assignee took advantage of this. In essence, the assignee has capitalized on a risk. Or, if the assignee would not have been able to make a profit, then per a contrario we would not have been in the situation where the author could rely on the incidence of the unpredictability, the more so since the theory of unpredictability mainly poses the problem of an excessive burden of obligation, and not on the lack of profit [5], [6].Obviously, we consider that by analysing the provisions of art. 43 par. (3) we will certainly encounter situations where the legal provisions regarding unpredictability will be incumbent, but we doubt the fact that whenever an author will base his claims on the provisions of art. 43 par. (3) the legal provisions of art. 1271 of the Civil Code will be incumbent, too.

In view of the above, we consider that the legal remedy established by the legislator in the provisions of art. 43 par. (3) of the Law no. 8/1996 has the characteristics of an unnamed legal remedy, which can not be fully assimilated to the exceptions of unpredictability or damages. The situation envisaged by the legislator in the provisions of art. 43 par. (3) considers, in our opinion, the situation in which the remuneration of the author becomes unjustifiably small during the course of the contract as compared to that of the assignee and is in the best interest of the copyright holder, in order to restore equitable remuneration. Last but not least, we appreciate that the theory of unpredictability generally 
addresses negative changes in the performance of a contract, while the restoration of contractual equilibrium may also be the case for a positive development of things. We reiterate the example of the author who assigns the right to reproduction and distribution for a small fixed amount, and then feels wronged by the high profit of the assignee generated by the over-expected sale of his book.

\section{Conclusions}

Obviously, the provisions of art. 43 par. (2) and (3) of Law no. 8/1996 may also be applicable by negotiating the parties to the contract, not only by virtue of the judgment. As we know, the court order resolves, based on law, the conflicts of interest between the two parties to the litigation. Otherwise, the modification of the contractual clauses by negotiation leads to the settlement of the conflict of interests.

\section{References}

[1] T. Bodoașcă, Contribuții la studiul reglementărilor legale referitoare la contractul de cesiune a drepturilor patrimoniale de autor, Revista "Dreptul” nr.4/2009, p. 133-135.

[2] V. Ros, Dreptul proprietatii intelectuale, Editura C.H. Beck,p. 388, 2016

[3] Art. 1221, par. (1) of the Romanian Civil Code

[4] T. Bodoașcă, I.L. Tarnu, Dreptul proprietatii intelectuale, Editia a III-a, revizuita si adaugita, Editura Universul Juridic,p. 104, 2013

[5] G. Beleiu, Drept civil român, EdituraUniversulJuridic, București, p. 196-201, 2007

[6] L. Pop, Ionut Florian Popa, Stelian Ion Vidu, Curs de drept civil. Obligatiile, Editura Universul Juridic,p. 528-540, 2013 